\title{
The Word against the Sword: Arabic Poetry in the Face of Despotism
}

\author{
Salaheldin Elgebily \\ Arabic Department, Hankuk University of Foreign Studies, South Korea
}

Copyright $(2017$ by authors, all rights reserved. Authors agree that this article remains permanently open access under the terms of the Creative Commons Attribution License 4.0 International License

\begin{abstract}
The relationship between authority and literature has been one of the closest and oldest relations. It originated when politicians realized the significant role of poetry in supporting political systems, or opposing them. The role which poetry played in ancient times is similar to the role played by the mass media in modern times; mobilizing masses and forming their lives. On the other hand, poets also realized the great influence of monarchs and politicians and the importance of their power over humans. The poets preferred being in the security zone next to the ruler, away from the circle of danger, in which the public are situated. To them, approaching the authority meant receiving grants, acquiring influential power and gaining the attention of broad sectors of people. This research is a brief attempt to understand the relationship between poetry and politics, and the enticements that mar it. It is a study of "the poets of rebellion and rejection", those milestones in the history of Arabic poetry, who stood in the face of the authority. Some of them paid their lives for their choice, while the others kept their lives, but they were marginalized and had to live on the outskirts of society.
\end{abstract}

Keywords Invective Verse, Rhyme, Encomiastic Verse, Political Poetry, Authority, Modern Arabic Poetry, Prose Poem, Muthaffar Al-Nawab, Mohamed Al-Maghout, The Modern Arab Poetry

\section{Introduction: (The Relation between Poetry and Authority)}

The relation between political authority and literature remains a strong one that began with the rise of each of them. Politicians realized the importance of writing and its serious role in supporting political regimes, creating their propaganda, defending, opposing or facing them. Actually, politicians are well-aware of their transient existence in this life. That is why they need to find a way to immortalize their glories. Did Sayf Al-Dawla Al-Hamadany know that he would be immortalized in history through the poems of Al-Mutanabbi, and that without the poetry of Al-Mutanabbi, he would not have received much attention in history books like other ancient kings? In the past, poetry played the role the media plays nowadays in influencing the masses $(1, \mathrm{p}$. 77); influencing their life style to the extent of a total belief in the crucial role of media in the absolute control of the masses. (2, p. 7-8)

On the other hand, the relation between poetry and politics began when poets came to the realization of the crucial importance of politicians like kings, princes, leaders and entourage and their infinite power over the masses. Poets were conscious - being frail humans, after all - that getting closer to politicians and being protected by a ruler can make their lives more stable and secure than ordinary people. Becoming attached to authority means receiving gifts, boons and money which the ruler bestows on his subjects. However, being close to authority does not only mean to be under its protection, at least one would avoid its violence.

This research is a brief attempt to understand the relation between poetry and politics, and their influences upon each other. It sheds light on those dissenters who declared disobedience and resisted the dominance of authority for any reason. Since this subject covers long spans of time that cannot be economized in such a small research, I have decided to point out the main phases of it in the history of Arabic literature and look at some of the poets of rebellion and rejection. Those poets who opposed authority and refused to speak for it to the extent that some of them met their end for their stance on the slightest pretexts; and others whose lives were spared, but led a death-in-life existence. They have been marginalized by the authority and its entourage.

At the beginning, I would like to define the meaning of authority which the poet would confront. In fact, creativity in all societies stumbles upon different types of authority that is not limited to the politically ruling one. It is true that the East has had its history of despotism since ancient times, and many researchers agree on the very relation between 'the East' and 'despotism": "The two words have become 
synonymous. It is true that many a nation has been ruled by despots; however, the East has been ruled by despots since ancient times" (3, p. 259). There is also the authority of society and its ruling and prevailing norms which could be a stronger power than the political one, to the degree of controlling and directing the political power.

Furthermore, there is the authority of religion, which has always tried to limit the freedom of art and creativity, and history has witnessed lots of oppositions between poets and religious men. Yet, I do not mean to say that religion is against art but would like to refer to those who rise in every age and gain power by giving themselves the divine right of interpreting the scriptures, and dictate what is right and wrong.

Moreover, there is the authority of critics. They usually define the essence of poetry according to the dictates of their times, and gradually acquire false authority. As a result, a poem, a painting or a piece of music cannot become art unless they give their consent. The classical books of Arabic criticism are loaded with theories of critics who only wanted to earn their living through poetry (4, p. 241-466). A significant example of this is what Abbas Al-Akkad did to the collection of poems "The People of My Homeland", by Salah Abdel Sabour. Abbas Al-Akkad considered the poems as prose; and refused to award their poet, as Al-Akkad did not accept "Modern Poetry" during that time. Al-Akkad regarded that as a rebellion against the accepted norms of Arabic poetry that have been adopted for ages.

\section{The Concept of Revolutionary Literature}

Some critics describe this literary genre in many ways; the most common ones are: "resistance literature", "rejection literature", or "rebellion literature". Yet, I prefer calling it "revolutionary literature" because the concept of revolution encompasses all types of resistance and rejection. Revolution is not merely an action of rejecting authority and resisting it, it is rather the creation of new concepts that replace the old ones. It differs from rebellion since the latter is a means of protesting against the status quo, without considering a new replacement.

Other critics believe that revolutionary literature is that which depicts a revolution, glorifies and foreshadows it. In fact, this definition is very limited to a great extent; for it does not differentiate between literature, the news and political speeches. Revolutionary literature "is that which seeks a radical change in society. This indicates that revolutionary literature is not only attached to revolution when it is carried out; but it paves the way to it, witnesses it and puts it on the right track after being conducted. It even contributes to its outbreak early before its advent. This is then a literary genre that reflects the contradictions of its reality and motivates the readers to persistently change that reality to the better" $(5$, p. 252$)$. Such a definition will indeed exclude much poetry that is labeled as "revolutionary". Revolutionary poetry motivates the reader to find his own answers.

A poet who does not rebel against the prevailing poetic norms is not revolutionary, in my opinion. We cannot here count on the differentiation between revolution as an action of political, social and religious emancipation, and revolution as a literary reaction against the stagnant literary forms of the past which force the contemporaries to do nothing but imitating them.

Discussing the definition of revolutionary poetry always leads to the serious question of conformity in literature. In this respect, critics have been divided into two groups: one, is a group advocating the absolute conformity of poetry and art, following the Marxist way, in which poetry becomes a mere tool of directing and enlightening the masses towards their disintegrated situation.. The other group, among which "Jean Paul Sartre" is the most eminent, liberates poetry from any conformity $(6$, p. 20). Likewise, the Iraqi poetess and critic Nazik Al-Malaika believes that forcing poetry into ideological conformity is a matter of absurdity, since it "demands stipulating what is irrelevant to the poem, the subject, and thus imposing an irrelevant dimension to the poem" (7, p235). This is almost the same opinion of Sartre who differentiates between prosaic writing and poetry. Yet, at the end, in my opinion we cannot detach poetry from conformity. But, settling down this problem requires the differentiation between "ideological conformity" and the "vision of the world" for the poet is not required to conform on the ideological level or he will transform poetry to a philosophical text.

This is what Naziq Al-Malaika and Sartre meant when rejecting conformity. They perceived conformity in its ideological sense, but when the poet conforms according to a "vision of the world", he places the ideas in their deep humanistic level.

\section{The Modern Arab Poet and His Stance towards Authority}

The relation between the modern poet and political authority greatly differs from that one in ancient times. There were almost stagnant traditions that had been accepted by generations since ancient times until the beginning of the modern age. I do not only mean breaking away from the unity of metre and rhyme; the impact has been deeper than that. They have broken away from many traditions that were accepted as part and parcel of Arabic poetry, to which the panegyric was a very important gate and through it poets competed with each other. The most famous ones are the first panegyrics and apologies that were written by Al Nabigha to Al-Nu'man ibn Al-Mundhir during Jahiliyyah, which have become a historic archetype:

$\mathrm{O}$ to plague leave me not, it is my blight 
For God has giv'n you power that shakes all knights,

Like the sun to stars, when rising they have but nights. (8, p. 28)

This poet is seized with terror due to the threat he receives from Al-Nu'man Ibn Al-Mundhir. He decides to send him apologies after as people avoid talking to him after knowing about his disagreement with the king. He becomes like a plagued camel, painted with tar. The poet reminds the king that God has given him power more than all other kings of his time; he portrays the king as the sun around which all the planets revolve. Surprisingly, the poet was not one of those petty poets who tried to benefit from kings through poetry. Moreover, classical books of criticism show that he was highly regarded by his folk. Ibn Qutayba says about him, according to Al-Asmaay, "A red tent was set up for Al Nabigha in Souk Okaz where poets showed him their poetry"(8, p. 167-168). Ibn Rashiq Al-Qayrawany also mentions that the Arabs did not earn their living through poetry until the appearance of Al Nabigha who "flattered kings in his poetry, gave in to Al-Nu'man ibn Al-Mundhir although his folk were enough support for him, or even his relation with the Ghassanids's kings. Yet, he lost his high position, earned a huge fortune, to the extent that he ate in plates of gold and silver given to him by kings" $(9$, p. 80). So, by doing this, Al Nabigha contributed in paving the way for poets to be close to authority even if they did not need money.

Thus, new generations of poets appeared, who knew their way to the courts of princes and kings, humiliating poetry and themselves. Later, some of them even used panegyric as a profession and gained wide authority. Some of them resorted to threatening those whom they flatter if they did not respond to their demands. The history books of literature are replete with such stories. For instance, the story of Al-Zebraqan Ibn Badr with the poet Al-Hutayaa (10, p. 11). Al-Hotayaa was feared by people and received gifts in order not to satirize them, to the extent that the Caliph Umar Ibn Al- Khattab put him in jail. Poets like Al-Aasha, Jareer, Al-Farazdaq, Bashaar, Abu Tammam, Al-Mutanabbi and Abu Nuwas were very famous for their ability to gain gifts from the flattered persons due to the good quality of their poetry.

Therefore, many a poet believed - because of the critics who made the panegyric a gateway, limited only to those who want to become great poets - that they have no other way for the mastery of poetry except for using the panegyric as a means of earning money.

Very few poets could break the shackles of that custody, as they did not take very much interest in the panegyric. For instance, the courtly poets, Umar Ibn Abi Rabi'ah and Abul Ala Al-Ma'arri. They refused to earn money through poetry either due to their social status, which denied such an act, or because they had other interests. A look on the poems of the ancient poets will show us that the panegyric is the main intention that dominates the major part of Arabic poetry, to the extent that a poet like Mahmoud Hassan Ismail, in the first half of the past century, dedicated a whole collection of panegyric poems to King Farouk, king of Egypt at that time. He did this although he was a small employee at the Egyptian Broadcasting and did not need to flatter neither princes nor ministers. However, these were firm traditions acquired by poets throughout time and which have made the panegyric a craft detached from reality. It is true that the poet condoned that collection of poems after the 1952 revolution and did not include them in his works. Nevertheless, looking on the introduction to these poems shows us how much the panegyric can be harmful to poetry: "Your majesty my king, this is the response of art to your newly glorious impact on all aspects of our life; for the love of you, I poured it out as an eternal melody that will echo your patriotism throughout eternity "(11, p. 341).

Ancient poets used flattery in order to receive gifts, otherwise they shifted their flattery into satire. For several years, Al-Mutanabbi remained the guest of Sayf Al-Dawla Al-Hamdani, flattering him all the time. Actually, what is peculiar about Al-Mutanabbi's poetry is his dignity which was never humiliated or humbled whatever the benefit was. Yet, that was an exceptional case in the history of Arabic poetry. However, a number of minor poets, who were full of envy and jealousy of Al-Mutanabbi, were finally able to turn Sayf Al-Dawla Al-Hamdani against him, in spite of their friendship. Consequently, Al-Mutanabbi left against his own will to Egypt and started flattering Kafur Al-Ikhshidi in pursue of a high position in the Egyptian state:

\section{Abu Al-Misk!}

Whose face I yearned to see, and meet that day

I have seen vast deserts with heights to his way,

Abandoned I wandered and the water stagnant it lay.

$\mathrm{O}$ father of Misk and all the scents of May,

And every clear cloud that goes by.

If people become elevated with the sight of dew,

You give what people wish according to your due (12, p. 443-444)

It seems that Al-Ikhshidi knew that Al-Mutanabbi had a certain intention behind these lines. Al-Mutanabbi was a distinguished poet, who desired more than what minor poets could ask for; he coveted to gain rule over one of the many Egyptian lands. However, Al-Ikhshidi temporised him. Consequently, Al-Mutanabbi understood that and had the intention of satirizing Al-Ikhshidi, then escaping from Egypt. He said:

Whenever a slave kills or betrays his master, Egypt is his resort

And a castrate becomes the runaways' Imam.

The free becomes a slave and the mortal humans are worshipped. 


\section{The Egyptian shepherds cannot see the Jackals}

For they are too stuffed with eating, yet food is abundant.

A slave can never be a free man even when being dressed like one.

Never buy a slave without a whip for they are sinful.

I've never imagined myself to be humiliated be a venerated slave $(12$, p. 507)

I do hope that my argument here would not be understood as belittling the artistic value of Al-Mutanabbi's poetry. After all, I am talking about him in light of the relation between poetry and political authority. Ancient Arabic criticism was able to erase the separating line between moral lying and artistic lying when it stated the famous saying "the more lies it contains, the more eloquent poetry is". This saying regards the leap of fantasy, depiction and tropes in general, which poets rely on, as a kind of lying. It is not clear to me, however, why it was described this way although the issue has nothing to do with morality. Nonetheless, the previous description opened up a door for poets to believe that they have to abandon any moral value if they wanted to be distinguished in poetry.

The modern age started with these concepts have already been established, and nobody could change them. That is why the classical Arabic pioneers like: El-Baroudi, Shawky, Hafez Ibrahim and Khalil Mutran did not find but these established poetic traditions to be rediscovered from a quasi-modern perspective. All the poems of the Arabic Neo-Classicists are full of panegyric and parody, following the old school. Ahmed Shawky was one of the most famous poets of the panegyric:

\section{Allah Akbar,}

The conquest is amazing, Khaled of the Turks revive the Arabs immortality

A dear pact after a great war, now the sword is in its sheath and Truth is shown

A desired wish fulfilled by the sword, and a dream that came true

Your steps towards Justice were benevolent as your nature $(13$, p. 59$)$

When we contrast this parody with the original poem by Abu Tammam on the conquest of Al-Ammureya, we can come up with important remarks:

War is more truthful than writing in being decisive

With white countenances with confidence and not shamed

The flag of victory is flying high among the glimmering spears

Where are the orators, even the starts and what they told was lying (14, p. 40)

The first observation is that the two poems have the same metre and rhyme scheme. However, what I find out in all Shawky's parodies, apart from his skill of using the same rhythm of the original text, is his unique ability to evoke the spirit of the original text and to charge it with passion not less than the original one. Additionally, the two poems were written after two conquests: the original poem was written after the victory of the Abbasside Caliph Al-Mu'tasim in the conquest of Al-Ammureya; the other was after the victory of Mustafa Kemal Ataturk in one of his battles against the West. So, Shawky did not find it wrong to evoke a text from the past and rewrite it newly. The most important thing here is that the poetical text deals with political authority in the same way the ancient text has dealt with it, as if the new text is a way of recycling the ancient one. I know that all types of art accept such acts, but the shortcoming with Shawky's text is that it did not go beyond the connotative meanings and rhythm. However, it imitated the apparent similarity between the historical events.

All in all, I do not have the least intention of charging that first generation of the Arab Neo-Classicists with the responsibility of using poetry for the benefit of political authority. Ahmed Shawky, for instance, regarded himself mainly as the poet of the ruling family and their fostered son in Egypt. He is the one to say:

Am I to betray Ismail through his sons?

And I was born in his own house!

\section{Modern Poets and Panegyric}

Flattering the Muhammad Ali Dynasty did not stop at Shawky's, the rest of the Arab Classicists did the same, like: Ali El-Garem, Hafez Ibrahim, Khalil Mutran and manyothers. Yet, I can assert that all of the artistic movements witnessed such a blending between poetry and political authority.

Thus, it can be said that the 1952 revolution in Egypt was the advent of many poetry that made Gamal Abdel Nasser and the dream of the Arab Union the main theme of the fifties and sixties' poetry in the past century. In poetry, Abdel Nasser was "a national hero by all standards, loved and venerated by people since he embodied for them the image of the Arabs' heroism, recalled to life from the dust of history. He was a member of the middle class, which he represented in every way, and he was biased to working men, peasants, the very poor and downtrodden. So, he inspired their imagination and got their support and gratitude" (15, p. 14).

In the poetry of Ahmed Abdel Muti Hijazi, and since his beginnings, the image of Abdel Nasser is that of a mythical hero, who can be found in the poetry of Al Nabigha, Abu Tammam, Al-Mutanabbi, Shawky and others. In one of his first collected poems "A City with no Heart" entitled "Abdel Nasser, Hijazi says: 
Ye poets should write I'm here

Watching the leader gathering the Arabs

And shouting "freedom, justice and peace"

Let tears mingle with words

And hide the wall of bricks

Even the two marble columns shall collapse

The balconies vanish

And erase the embellishments

So the human be above all this

And opens the doors for our entourage

Ye poets and historians of time

Write about a poet that was here

And lived in the time of the great Abdel Nasser (16, p182-183)

Although this poem is fairly short, it summarizes much of the previous discussion. The leader is an exceptional being who is different from the ephemeral human beings. Once he appears waving his hand to the crowds, the hearts become attached to him like the Greek gods. The very mission of the poet here is to reflect whatever the god-like leader says, for poets are "the historians of times"; and, historians must record whatever the leader says. The poet here becomes larger than life once he is happy to live under the reign of such an inspiring leader. I hope it is clear enough that such a stance by poets in creating layers of accumulated oppression is dangerous.

It is a whole pattern of an authoritative culture founded by that kind of panegyric poetry. In the end, the whole thing is a materialistic benefit for the poet regardless of its sinful impact after that.

Here, we can use Cultural criticism to point out the idea we want to clarify. Poetry is not just a beautifully formulated language. It is a medium of whole cultures, encompassing many signs that affect the reader without his being conscious of that. The effect goes far beyond a linguistic game between the flatterer and the flattered that is played by the poet. We need to agree that poetry for the Arab citizen is much more than a means of enjoyment. Poetry is a main constituent of the Arabic character. It was described by Omar Ibn-el Khattab as "the account book" of the Arabs: "Poetry is the diwan of the Arabs". He also said: "Poetry was the science of people who perfected it" $(17, \mathrm{p} 24)$. Therefore, poetry is not just a means of pleasure or merely an embellished language; it is a cultural component that affected many generations from Al Jahiliyya Period until our modern times. This happened even after the appearance of the media, which could not completely replace the role of poetry, at least in the Arab world. It is true that poetry is no longer the backbone of the Arabs as it was in the past, yet it is still surviving and struggling. It is really necessary that we should stop repeating the saying that poetry is only a means of expression. This "reflects very dangerous and wrong patterns which we believe were the reason behind the shortcomings of the Arabic character itself... No doubt the more serious invention of the flatterer and the flattered game has brought about a pattern of values that have been firmly established through time and have formulated the social relationships between people. The culture of flattery that is founded on lying while both parties of the flatterer and the flattered and the surrounding intelligentsia before and after them, they all accept and have accepted the game of lying and hypocrisy. They participated in the game and enjoyed it until it has turned into a cultural and social norm" (18, p. 93-94).

\section{Revolutionizing the Literary Text, "Authority" of the Past}

It was not the habit of all poets to be hypocrites or to flatter the rulers in a cheap way to gain money, or to avoid their wrath, which no one could escape. These were greatly harmful flatteries to the set of values that formulated the life of the Arabic society. They were a way of glorifying oppression and officially founding political and social hypocrisy, which only few ancient and contemporary poets could escape. While there were poets reared by authority, served its end and scavenged its money, there were other poets who declared their disobedience and refused for many a reason to use poetry as a means to their end. I do not mean to misplace those poets, or to talk about imaginary heroism that makes them mythical heroes. At the end, they are infallible human beings. I mean here the rebellion of a poet like Bashaar Ibn-Burd against the blindly accepted norms of the panegyric by the poets of his time. Can this be not regarded as a kind of heroism in contrast to the state of tyranny and deifying the rulers that people witnessed during that time?

Ancient stories tell us about the end of Bashaar Ibn Burd $(19$, p. 95,20 , p. 19). These stories emphasize the fact that Bashar satirized the Caliph Al Mahdi through his minister Yakoob Ibn-Dawood and said:

\section{Bany Umayya shake off your long sleep \\ Your true Caliph is Yakoob Ibn-Dawood. \\ The Caliphate is lost, for your Caliph \\ Can be found amongst wine and music.}

In the previous lines, Bashaar implicitly belittles the Caliph Al Mahdi, for he sees that Al Mahdi is not good enough to be the Caliph, and the real Caliph is the minister Yakoob Ibn- Dawood, while Al Mahdi has nothing to do with real authority.

Moreover, our heritage tells us that Al Mahdi came to Basra one day and heard the call to prayer " $\mathrm{Al}$ Athan' before noon, when it was not the right time for prayer. As he listened carefully, he found out it was Bashaar who 
announced it and thought that he was drunk. So he ordered Bashaar to be whipped before him. Bashaar had been whipped seventy lashes before he felt he was dying. Then, he was thrown onto a ship until he met his final end. After his death, his body was thrown in the desert. Afterwards, his family took his body to Basra to be buried there. Bashaar had a very abusive tongue that nobody could escape, that is why people were happy at his death. He was also boastful of drinking wine publicly, quick-tempered and quick to satirize. But, the circumstances that surrounded his death and the way he died are fairly strange to me. For he was past his nineties at that time, in addition to having written panegyrics to $\mathrm{Al}$ Mahdi, which means that his rebellion against Al Mahdi was an exceptional act. However, Bashaar Ibn-Burd was not the only poet killed due to his writings; Saleh Ibn-Abdul-Quddus and a number of other poets were accused of becoming atheists. Some writers even were accused of the same thing, such as Ibn Al-Muqaffa', the translator of the famous book "Kalila wa Dimna". Actually, this is a topic that needs extra analysis and which the research at hand cannot fully cover.

\section{Obscene Poetry in contrast to Obscene Reality according to Mudhaffar Al-Nawwab}

To begin talking about Mudhaffar Al-Nawab, I find nothing better than the words with which he introduced his collected poems; simple, but deep and significant: "Forgive my melancholy, wine, wrath and my harsh words. Some will say this is obscene... It is fine... Show me something more obscene than our status quo". The poet here is aware of the weapon of authority which is ugliness, and it can only be defied in the same way, or even in an uglier one.

There are many poets whose poetry is loaded with many terms, which -in my opinion- should not be used. Poetry is a sublime kind of art and the poet should not be influenced by that state of triteness. A true poet has to be the "anti-ugliness" of authority. The issue of opposing the discourse of authority might seem an easy task for the artist, since his stances are definitely different from the stances of authority and institutions. However, to be just an "opposition" is one thing and to present an "aesthetic" kind of opposition is another. It is not easy to stick to the ethics of battles either in writing, politics or in the war arena. Therefore, if the poet gave up the aesthetic aspect of his writing, what would differentiate him from any other kind of opposition?" (21, p. 193). On the other hand, we should differentiate between expressing triviality and the triviality of expression. We should follow the saying that poetry in particular and literature at large use different language from that of the tyrants. It is a language of the beautiful and the sublime.

Mudhaffar Al-Nawwab says in his poem "Jerusalem is the Bride of your Arabhood":

I confess now before the desert
I'm obscene and vulgar like your defeat, you vanquished nobility

Vanquished rulers

Vanquished crowds

How squalid, squalid, squalid we are

And we deny it

How squalid we are

I do not make any exception, do you know

I said: I - am - obscene

Despite melancholy

And pouring ablutions for my drunk state

And licking that thigh next to the pub's door

We would turn into the Jews of history

And homelessly howling in the desert

Can this be a home that is ruled by royal thighs?

Is it a home or a brothel?

Can this earth be a land or a den of wolves?

What is peculiar about these times and pimping the peaceful ways?

What is the meaning of this Arab masturbation in face of the peace projects?

And drinking the toast of the bastard "Ford"? (22, p. 336)

In previous times, the poets did not dare to use such words in their poetry, at least in public. I know that Abu Nuwas, Ibn Al-Rumi and others used some linguistic audacity, but these were exceptional cases after all. The question here is: can the value of poetry be measured by the number of such words? In fact there is no relation between the use of particular words and the value of poetry. The value of a word in poetry is defined by the poetic context; no word can be regarded as poetic or not unless within a poetic context. Whereas, loading all these words within a limited poetic context, the text becomes totally unpoetic. In my opinion, the poet could have condoned all this ugliness by trying to create an aesthetic effect of the poem that reflects, by its implications, the ugliness that the poet wants to express. One cannot express the triviality of reality in a trivial and low way, or reflect superficiality and triteness in a superficial way. The whole matter at the end is Art, and one should stick to the simple ethics of it. Above all, being involved in such a disintegrated way of expression can be an endless road.

Mudhaffar Al-Nawwab says in the same poem:

Jerusalem is the Bride of your Arabhood.

So, why have you let all adulterers enter her room? 
And stood eavesdropping behind the doors, listening to her virgin screams,

And you dragged your swords boasting of honour

And shouted at her to stop her yells for the sake of honour

How honourable you are!!!

Sons of bitches, how should a raped virgin be silent?

I'm not ashamed to tell you the truth;

That a pigsty is more virtuous than the most virtuous of you.

Analyzing the previous stanza of the same poem to illustrate the deviation in the language of Mudhaffar Al-Nawwab serves well in explaining my previous perspective. The poet could have completed the image of Jerusalem as a raped virgin with the Arab rulers heedlessly looking at her. He could have even asked the city not to yell for the sake of saving her honor. But, the poet preferred to yield to the easy way and he gave in to banality. The poet believes he is obliged to do this due to the disintegrated reality of the Arab world. "I cannot resort to the realm of ethics while drinking hemlock to fullness. Resorting to mild and soft diction while living the hell of oppression would be a lie. Shame on me that while living this prevailing humiliation of the Arabs that my diction would not be "up to" that linguistic "abyss". Resorting to silence in face of abasement and suppression is treason... My scream is as big as my pain. Disintegration should be faced with disintegration. We are witnessing various forms of obscenity. We are witnessing suppression on the coloured screens of the media; we are witnessing adulterous silence or silent adultery in its latest trends. So, which diction would you like me to choose?" (23).

Actually, such rhetorical speech by the poet should not stir our emotions at all. After all, we all agree that he writes poetry; and, since he does not write a political speech or a political article, he should stick to the basic rules agreed on by poets. The poet who gives in to such obscenity chooses the easiest way. There is a much more difficult road through which the poet creates a highly crafted poetic structure, which reflects the tragedy without being involved in such obscenity, for he knows that at the end he writes a poetic text not a political petition. If such a perspective "the more tragic the events are, the more obscenity should be used" is accepted, we should be assured that one day poetry would become a game of insults; and this would move us immediately from the context of poetry to its opposite. Under the pressure of this oppression and disintegration on all levels, the poet is not asked to look for soft words that touch our feelings. He is asked to reflect the tragedy in a poetic way, and no poet can do this except one who is aware that the poem which loses its poetic aspect for the sake of popularity, will quickly pass into oblivion. Only real poetry can stand the test of time, not political insults.
The most important thing about this experiment - in light of the subject of this research - is that the poet wholly rejects the political regime and hates it without any hope of a compromise. His political poetry is characterized by "sarcasm, irony, insult and indecent language, especially when describing the Arab rulers" (24, p. 21), to the extent that the poem sometimes becomes a political battle, in which poetry is only a superficial, external form, that rapidly cannot stand the force of political obscenity. I believe that poetry is the loser in this battle.

\section{Muhammad Al-Maghout... the Mild Rebel}

Talking about political poetry in the experience of Muhammad Al-Maghout takes us down a different road. Muhammad Al-Maghout - in my opinion - is one of the best Arabic poets, of whom we can honestly say that he has added to our Arabic poetry a new poetic taste, which is totally different from his predecessors and successors. He is one of a few poets who could write an Arabic prose poem. Most of the experiments of poets who wrote the prose poem, only produced disfigured imitations of European literature. The Arabic prose poems shocked the Arab reader who had been accustomed to hear the rhythm of a rich heritage of ancient Arabic poetry. It also appeared as an imitative form of French and English poetry. That is why the prose poem became a foundling son that nobody wanted to acknowledge. All of the prose poems by other poets were forgotten. Only the poems of Muhammad Al-Maghout have stood the test of time.

Unlike the other genres of poetry, meaning in the prose poem is very ambiguous. It is different from those poems of Nizar Qabbani, Moaeen Bassisso, Ahmed Abdel Moaty Hegazi and Muthaffar Al-Nawwab. When a poet chooses to write a prose poem, he freely relinquishes many of the rhetorical devices which evoke the feelings of his readers. He gives up rhythm; which, in poetry at large and in political poetry in particular, is of crucial importance. The prose poem mainly rejects the traditional elements of poetry. It is rebellious against everything. A heap of various subjects and ideas. Sentences in the prose poem do not succeed each other like in traditional poetry.

Al-Maghout's prose poem does not unfold itself fully to the reader like all great poetry; it always needs a second reading. The poetic forms of the prose poem have their roots in the culture from which they come, and to be embedded in its new environment, some modifications should be made to the poem.

His poetry is not characterized by straightforward depictions and the hyperbole of rhetoric. It does not accuse a particular person, or his political regime, as an unjust ruler; it has an omniscient outlook. Al-Maghout sees tyranny as part of the Arabic society in the meantime. It resides over all the Arab citizens who live in an ongoing terror of the political 
authority. But, at the end, they live with the ideas of that authority and do not differ greatly from it. The Arab citizen is always frightened of something monitoring him. Monitoring is part of his being, no matter he tries to forget it:

Whenever there's a knock on the door, or whenever a car moves

I hide my papers with my hands

As a whore when caught

Who has left me this terror?

This horrified blood like a mountain rat?

Once I see an official announcement on a doorstep

Or a hat from the crack in the door,

My bones clatter and tears run

My blood runs frantically in all directions

O my love

In vain, I restore my courage

The tragedy is not here

It is not in the whip, the bureau, or the warning alarms

It's there in the cradle... in the womb

I was not indeed

Tied to my uterus with the umbilical cord

But with a hanging rope. $(25$, p. 200$)$

Here, the political satire changes from being directed to someone to a more general state of society that is embodied by the ruler. The Arab citizen lives in continual terror of everything. The reader does not need too much reflection to understand that this oppressive atmosphere seems to control the lives of the Arabs from womb to tomb. The poet is always trying to get rid of it, however, he discovers that it is far more complicated and deeper than it seems. So, he imagines it to be part and parcel of his genes. Here is manifested one of the most important constituents of the prose poem in general, which is the use of dramatic irony and hidden sarcasm of everything. The prose poem rejects any intellectual or religious restrictions. It is very audacious in transcending taboos:

Ye peasants in all the lands

Send me all what you have

Of flowers and rags

All the torn bosoms

And the wombs that had been ripped open

The pulled out fingernails

To my address at any coffee shop

In any street of the world
I'm preparing a huge folder

About human suffering

To send it to God

As soon as it is signed by the hungry lips

And the eye lashes of those who wait

But, ye desperate everywhere

What I truly dread

Is that God might be "illiterate" (25, p. 185-186)

One characteristic of prose poetry can be seen clearly in the previous poem, which is brevity, or what is known by critics to be the "Aesthetics of Minimalism". It is a genre that does not use irrelevant embellishments or hyperbole. Every word suits its context. It has no extra additions or exaggerations, and no external implications that are not necessary. What is peculiar about Al-Maghout's poetry is that it does not shock the reader and drag him to the accustomed enigma of the prose poems of Adunis, Onsi Al Haj and others who were satisfied by theorizing without succeeding in creating prose poetry that can reach the readers. The only poet of that generation, who could create a bond between himself and his readers, is Al-Maghout. Whereas the rest had been entrapped in riddles, extreme subjectivity and ambiguity. Al-Maghout in his poem "An Arab Traveler in Space Stations" says:

Ye Scientists and technicians

Give me a passport to heaven

I'm delegated by my melancholic homeland

In the name of its widows, old men and children

So that you can give me a free passport to heaven

For in my hands instead of money.... There are "tears"

Have I no place?

Put me in the rear of the car... on its back

I'm a peasant and I am used to this

I won't hurt a star... and I won't offend a cloud

All I want is to reach

The sky with ultimate speed

To put the whip in God's hand

That he may urge us to revolt $(25$, p. 207)

In his poem "Terror", Al-Maghout uncovers the superficiality of the Arabs' societies. He shows the fake world we are living in. He wishes to go back to his innocent childhood, and live next to his rustic mother. All his surroundings terrorize him. He fancies waking up one morning to find himself tied up and slain. He carries his identity documents everywhere he goes, as if a stranger who 
has no home:

I'm afraid to wake up one morning

And not find a bird on a tree

Or a flower in a braid

Or a friend in a coffee shop

I'm afraid to be tied up one morning

To the washing machine or to the hearth

To be flooded by bullets and the currycomb in my mouth

I enter the bathroom with my identity documents in my hand

I leave the coffee shop, turning left and right

Even the little bud turns left and right

Before it blossoms (25, p. 204-205)

\section{Conclusions and the Important Results}

This research studies the relationship between poets and political authority in modern times. I have chosen two of the major and most distinguished modern poets: Mudhaffar Al-Nawwab and Muhammad Al-Maghout. Before that, I mentioned that the relationship between poetry and politics back to ancient times.

I had to clarify the meaning of revolutionary literature as a literary term, and I differentiated between opposition, rebellion or rejection. I said that the concept of revolution is broader than all these actions, for the revolutionary poet is the one who has a complete vision against the ruling authority, and is not limited by the action of opposition a poet cannot be a real revolutionary unless his poetry rebels against the stagnant literary traditions.

I pointed out the dangerous impact of the panegyric and apologies. I saw that Al-Nabigha started one of the most awful shortcomings in Arabic poetry. He started the eulogies, which belittled the poet, who, in his turn, becomes insignificant in contrast to the flattered person, and through which the poet receives gifts by the flattered.

Literary history has transferred that heritage from the ancient to the modern poets. A renowned poet like Mahmoud Hassan Ismail wrote collected poems in praise of King Farouk. Even some poets wrote many poems in praise of Gamal Abdel Nasser. The most prominent example that I gave of opposition was Bashar Ibn-Burd, who was slain according to the orders of the Caliph Al Mahdi.

I have studied the political approach in the poetry of the Iraqi poet Mudhaffar Al-Nawwab. In fact I chose that poet for his poetry is characterized by a political satire that can be directly understood. Yet, it is an obscene satire. The poet saw that his obscene language was an expected reaction against the disintegration and humiliation of the status quo of the Arabs. So, the poet defends his poetry that is full of offensive and unsuitable language on the pretext of the humiliating reality. In his opinion, under the pressure of these demeaning circumstances of the Arabs, a poet cannot write fancy romances. However, on the contrary of the poet's opinion, I have said that the poet is an artist, he should not describe such situations with obscene language and should not depict disintegration through disintegrated poetry. I have said that the poet is the "anti-ugliness" of authority. The poet should not relinquish his good manners to match the ugliness of authority; otherwise he would not differ from it. Poetry is a fine art that can reflect the tragedy of life through the genius of the poet, and his search for the technical means that can convey that tragedy. Yet, when the poem becomes a political speech that is full of yelling and obscene language, it cannot be considered poetry at all.

At the end, I touched upon one of the best experiences by an Arab poet, which is the experience of Muhammad Al-Maghout, who took poetry down a different road and did not use metre or rhythm and many other traditional forms of ancient Arabic poetry. It is as if he was starting creativity from scratch. It is true that creativity cannot start from nothing; however, he was a unique poet, who could use unknown poetic forms to the Arab society and make a number of modifications to them, so as to make them suit their new culture. Writing and reading a prose poem is a very difficult task for both the Arab poet and reader. Many poets tried writing it but their poetry passed into oblivion and was read by no one. Their poetic experiments could not stand the test of time. However, Muhammad Al-Maghout could create through the prose poem new Arabic poetry per se. At the end of the research, I tried to detect the most prominent political features of his poetry. Political condemnation in Al-Maghout's poetry is not just limited to the ruling class, which is embodied by the king or the president as we find in Mudhaffar Al-Nawwab's poetry. Al-Maghout realized that tyranny in the Arabic societies is too deep to be embodied by the image of the ruler. Every citizen of the Arabic society suffers from tyranny, as if tyranny has been combined with their genes. Condemnation in his poetry is for the whole society and not just the ruler. In fact, I chose only those two poets in order not to elongate my research, yet the issue needs more poets to be studied.

\section{REFERENCES}

[1] Stephen C, Karen R. The Media and The Public. Cairo: Al Fajr for Publishing and Distribution; 2012.

[2] Chomsky N. Media Control. Cairo: Al Shurouk International; 2003.

[3] Imam IAF. The Tyrant. Kuwait: The Supreme Council of Culture and Art; 1994. 
[4] Abdel Rahman R. The phenomenon of Earning Money through Poetry and it's Presence in Ancient Arabic Criticism. Al Azhar Periodical. 2010; 12(1): p. 241-466.

[5] Al Bahrawy S. Issues of Arabic Criticism and Creativity. Cairo: General Authority for Cultural Palaces; 2002.

[6] Sartre JP. What is Literature? Cairo: Nahdat Misr for Publishing; 2005.

[7] Al Malaika N. Issues in Contemporary Poetry. 5th ed. Beirut: Dar Al Elm Lel Malayeen; 1978.

[8] Al Dhubyani AN. The Poems of Al Nabigha Al Dhubyani. Abdel Sattar A, editor. Beirut: Dar Al Kotob Al Elmeya; 1996.

[9] Al Qayrawani IR. Al Omda. 5th ed. Abdel Hamid MMAD, editor. Berut: Dar Al Jeel; 1981.

[10] Al Hutayaa IA. The Poems of Al Hutayaa. Explained by Ibn Al Sakkit Kumayha MM, editor. Beirut: Dar Al Kotob Al Elmeya; 1993.

[11] Ismail MH. Complete Poetry Works. Cairo: General Egyptian Book Organization; 2004.

[12] Al Mutanabbi IAH. The Poems of Al Mutanabbi. Beirut: Dar Beirut for Publishing and Distribution; 1983.

[13] Shawky A. Al Shawqeyat. Beirut: Dar Al Awda.

[14] Azzam MA, editor. The Collected Poems of Abu Tammam. Illustrated by Al Tabrizi, Al Khatib. 5th ed. Egypt: Dar Al Maaref.
[15] Sorour A. Abdel Nasser in Modern Arabic Poetry. Alexandria: No Poblisher.

[16] Hegazy AAM. The Poems of Ahmed Abdel Moaty Hegazy. Beirut: Dar Al Awda; 1982.

[17] Al Jumahy MIS. Great Poets Classes. Shaker MM, editor. Jeddah: Dar Al Madany; 1974.

[18] Al Ghathami A. Cultural Criticism: A Reading in The Arabic Cultural Patterns. 3rd ed. Morocco: Arabic Cultural centre; 2005.

[19] Al Asfahani AF. Al Aghani. Beirut: Dar Ehyaa Al Turath Al Araby; 1994.

[20] Manna H. Bashar Ibn Burd. Beirut: Dar Al Fekr Al Araby; 1994.

[21] Ghazoul FG. Poetic of Anti-Agliness. The Poetry of Eighties: The Palastinian Model. Fusul. 1986/1987 October/March: p. 193.

[22] Muthaffar AN. Complete Poetical Works Beirut: Dar Qanbar; 1996.

[23] Hassan F. Al Hewar. [Online].; 2009 [cited 2016 February 22. Available from:

http://www.ahewar.org/debat/show.art.asp?aid=188017 .

[24] Hemdan NAL. Language in The Poetry of Muthaffar Al Nawab Naples: University of Al Nagah Al Wataneya; 2012.

[25] Al Maghout M. Poetic Works. Demascus: Dar Al Mada; 2006. 